\title{
RESEARCH OF VIBROACOUSTIC METHOD OF TECHNICAL CONDITION CONTROL OF DIESEL ENGINE OF COMBINE HARVESTERS FOR DETECTION OF DEFECTS APPEARANCE
}

\author{
D. I. Martyniuk
}

National University of Life and Environmental Sciences of Ukraine. Ukraine.

Speciality of article: 133 - industry engineering.

Corresponding author: martyniuk94dima@gmail.com.

Article history: Received - January 2020, Accepted-April 2020.

Bibl. 16, fig. 6, tabl. 1.

Abstract. The authors research the vibroacoustic method of technical condition monitoring the diesel engine of combine harvesters as result of analysis of propagating elastic vibrations through the block and details interaction. Therefore, the authors solved the problem of this method the detection of vibrating acoustic signal caused by interaction of details of studied kinematic pair. The decision took into account that increase in number of cylinders of engine leads to increase in density of vibration pulses per phase space unit, so cycle of operation of combine harvesters' diesel engine was estimated by angle of rotation of crankshaft. Therefore, it is established that only phase space of gas distribution mechanism is filled with vibration pulses, that it is impossible to determine the technical state of the i-th connection of this mechanism by one parameter. To improve the accuracy of diagnosis, the authors considered the nature of oscillations in combine harvester engine. Engine work is characterized by the fact that workflows in different sections pass at different periods of time, so they use temporary selection to distinguish the vibrational process associated with work of single section or single element of one section. The impact of fluctuation of engine is impulsive, caused by high rate of increased pressure in combustion chamber, by transfer of pistons and processes of fuel injection. Therefore, changes in moment of fuel injection, malfunction of gas distribution mechanism, wearing of piston rings and increasing in gap between piston and sleeve are related to operation of these mechanisms, so the pulses shift in phase, their amplitude and duration change and new pulses appear. At the same time there are several factors that cause some kind of complication of vibroacoustic signal. For engines with more than 5 cylinders, signal timing (overlapping) and imbalance of parts during rotation causes appearance of $606.5 \mathrm{~Hz}$ frequency spectrum.

Key words: vibration signal; defect; amplitude; fluctuation; engine.

\section{Introduction}

The vibroacoustic method of control of the technical state of the mechanisms of tractors and cars and their power plants is based on the analysis of elastic oscillations propagating on the frame and parts, as a result of the interaction of the latter [1]. In this regard, one of the main tasks of this method is the distribution of signals [2], that is, the detection of vibroacoustic signal caused by the impact of the details of the studied kinematic pair [3].

\section{Formulation of problem}

Currently, a fairly wide range of methods and means of diagnosing the technical condition of the main units and mechanisms of tractors, including the internal-combustion engine (ICE) is used [4]. The new systems of maintenance, repair and means of technical diagnostics of machine units have been created [5]. One of the directions in the field of machine operation for today remains the task of increasing the reliability of the engine [6], through a comprehensive assessment of the condition of the units based on the temporary collection of diagnostic parameters [7].

\section{Analysis of recent research results}

The possibility of detecting faults at the initial stages of their emergence at relatively small labor and material costs determine the perspective of diagnosing of ICE by vibration signals [8]. Ensuring the predicted reliability of the conclusions regarding the state of mechanisms and systems, it can be achieved by using a statistical evaluation of the conformity of temporal frequency fragments of vibroacoustic signals and their conformity to the frequency of rotation of the crankshaft [9]. The use of modern compact measuring modules with low energy costs provides a possibility of designing and production of diagnostic devices in mobile execution, for installation directly on the tool during testing [10]. Thus, research 
aimed at developing a methodology for diagnosing mechanisms and systems based on the evaluation of vibroacoustic signals generated in the case of ICE during operation, as a method of control is quite relevant for agriculture [11]. Moving machine parts in contact with each other generate vibrations and sounds. However, the surface of any parts cannot be completely smooth. The surface roughness is one of the causes of vibrations at the narrow local contact of two friction surfaces, which are mutually moving [12]. There may be dry sliding or rolling friction as well as hydrodynamic friction when the friction surfaces are separated by a layer of oil or other lubricant [13].

The vibrations of the ICE case are complex (Fig. 1: 1 - the source of emergence of shock vibrations; 2 - the first stage of propagation of vibrations (conjugation of the stripper fingers - the upper head of the rocker); 3 - the second stage of propagation of oscillations (the connection of the lower head of the rocker - rod neck of the crankshaft); 4 - the third stage of propagation of oscillations (connecting the root neck of the crankshaft block); 5 - the first stage of propagation of oscillations in the other direction (conjugation of the piston - cylinder); 6 - resistance to propagation of vibrations (gasket); a, b, c and $d$ are areas of rational withdrawal of information.), due to the many impulse excitation and multichannel propagation of oscillations, as well as the presence of uncontrolled "noise". Therefore, a difficult task is to separate the signals and isolate the signal from the connection being diagnosed [14].

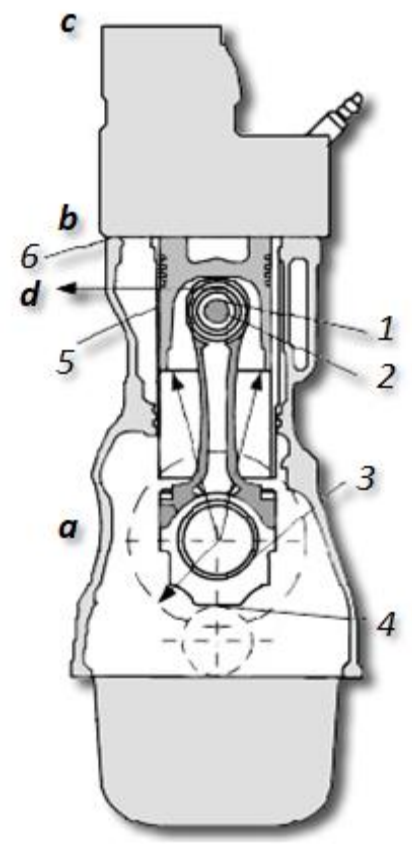

Fig. 1. Dissemination of information about contact of parts in the combination of the finger-piston at the end of the release cycle.

\section{Purpose of research}

The authors research the vibroacoustic method of technical condition monitoring the diesel engine of combine harvesters as result of analysis of propagating elastic vibrations through the block and details interaction.

\section{Results of research}

One of the main tasks of the vibroacoustic method is the distribution of signals, that is, the detection of vibroacoustic signal caused by the impact of the details of the studied kinematic pair [15]. The difficulty of this task is that the increase in the number of cylinders leads to an increase in the density of vibration pulses per unit phase space (the cycle of operation of the internal combustion engine on the angle of rotation of the crankshaft) [16]. Thus, in the SMD-31A engine, the phase space only from the gas-distributing mechanism is filled with vibrating pulses so (Fig. 2) that it is impossible to determine the technical state of the $\mathrm{i}$-th connection of this mechanism by one parameter. In order to improve the accuracy of diagnosis, the evaluation of several diagnostic parameters is needed.

The nature of the vibroacoustic signal of the ICE mechanisms has a complex structure, which depends on the dynamics of the mechanism and the set of components. Analysis of the literature [16] allowed us to determine the parameters of the installation of the vibration sensor (location and method of fixing). The following mounting methods were chosen - on the stud, and with the help of a special mount. Attempts were made to secure the sensor with an epoxy resin, but given the long installation time, this method was considered as not perspective. The vibrating signal emitted by the connection was perceived by the vibration sensor (B\&K Type 4333 No272437, D-14, IS-317). Before installation, the sensors were calibrated. To evaluate the condition of the units and mechanisms of the internal combustion engine with the help of a vibration transducer the sensor was pressed to different zones of the motor installation (Fig. 3), selected the necessary mode of operation of the engine and recorded signals to the computer for the next analysis and processing. Simultaneously with the removal of vibration parameters in the frequency spectrum, the position of the piston of the first cylinder relative to TDC (Fig. 3) was determined using an inductive speed sensor.

Consider, for example, the nature of the emergence of oscillations in the ICE. Engine work is characterized by the fact that workflows in different sections pass at their own times, so they use temporary selection to highlight the oscillation process associated with the work of a single section or a single element of a single section. The nature of the excitation of oscillatory processes of the ICE is peculiar. A characteristic feature of it is the impulse nature of the excitation caused by the high rate of pressure increase in the combustion chamber, the transfer of pistons, the processes of fuel injection and exhaust.

When changing the parameters of the engine, such as the moment of fuel injection, disturbance in the gas distribution mechanism, the wear of the piston rings, the increase in the gap between the piston and the sleeve associated with the operation of these mechanisms, the pulses are shifted in phase, their amplitude and duration change, new pulses appear. At the same time there are several factors that cause complications of the vibroacoustic signal. For engines with a number of 
cylinders more than 4 coincidences in time (overlay) of signals, and imbalance of parts during rotation leads to the appearance in the signal spectrum of frequencies multiple to rotation speed (Table 1).

The examples show the complexity of the oscillation processes that occur in the engine. Therefore, the selection of a useful signal in the diagnosis of a particular node is associated with certain difficulties, which are greater when reducing the number of channels of measurement. On the one hand, the solution is to provide each of the connections with its own vibration sensor, which would allow the signals to be separated in time by significantly attenuating the signal as the distance from the oscillation source increases. However, this approach leads to considerable material costs. The best approach is to use one or two sensors (maximum 4) and provide a reliable signal processing algorithm to identify the source of oscillation. In this regard, a perspective and effective way of technical diagnostics of the engine is considered to be time implementation (Fig. 4) and frequency analysis.

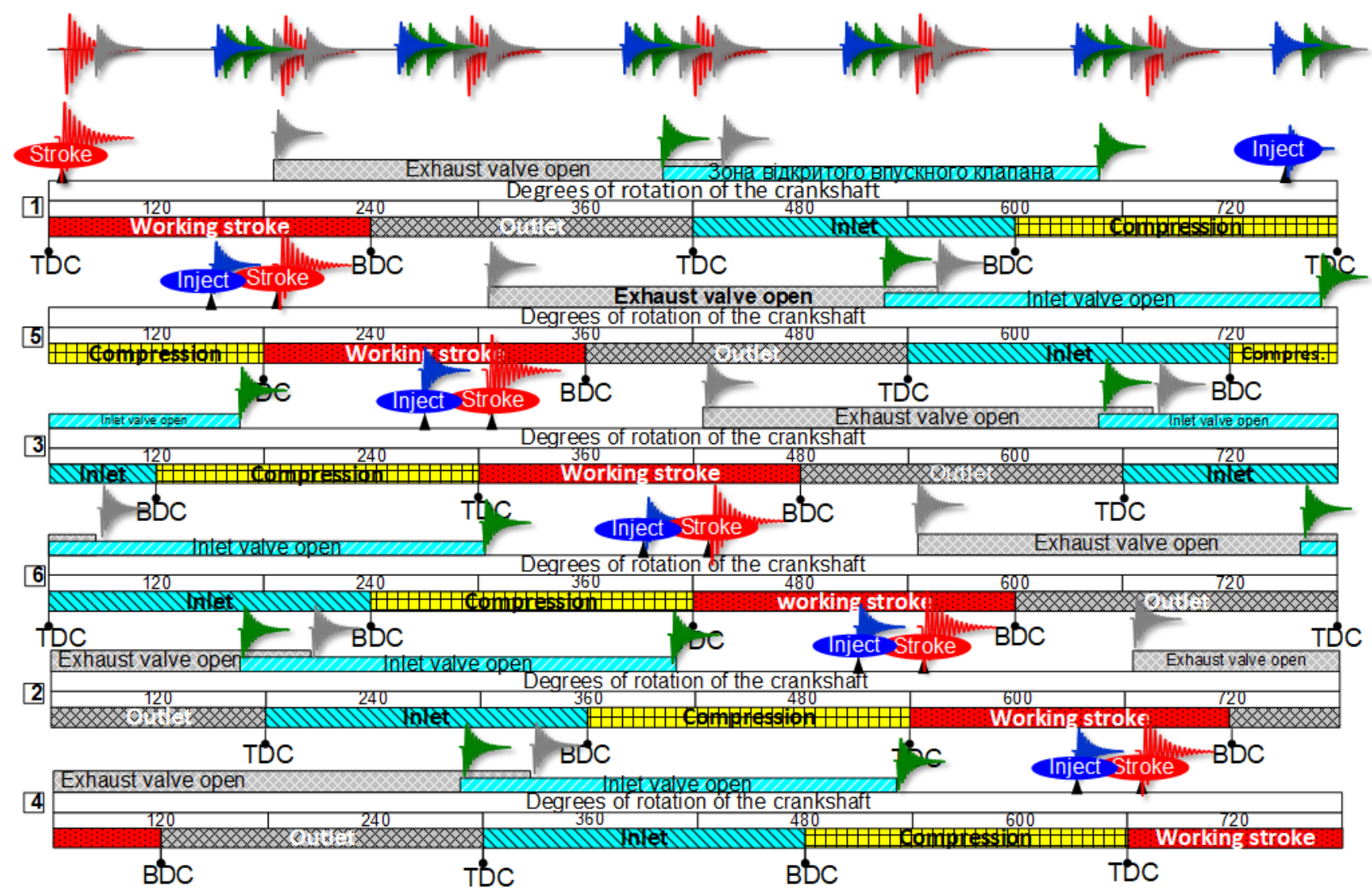

Fig. 2. Theoretical diagram of blows from the gas-distributing mechanism, the fuel equipment, cylinder-piston group on separate cylinders of the engine SMD-31A and their phase realization.

Table 1. Determination of frequencies of main driving forces in ICE.

\begin{tabular}{|c|c|c|}
\hline Cause of vibration & Formula & Denotation \\
\hline $\begin{array}{l}\text { 1. Imbalance of rotating parts, inertia } \\
\text { forces of the first moment and their } \\
\text { moment, } f_{D I}\end{array}$ & $f_{D 1}=\frac{k n_{D}}{60}$ & 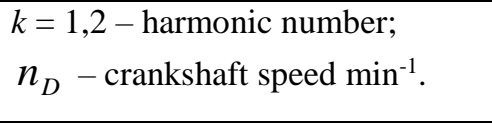 \\
\hline $\begin{array}{l}\text { 2. The process of combustion of fuel, } \\
f_{D 2}\end{array}$ & $f_{D 2}=\frac{c}{2 D}$ & $\begin{array}{l}c-\text { speed of sound at combustion; } \\
D \text { - diameter of the cylinder. }\end{array}$ \\
\hline $\begin{array}{l}\text { 3. Imbalance: } \\
\text { - second-order rotating parts, } f_{D 3} \\
\text { - camshaft parts, } f_{D 4}\end{array}$ & $f_{D 3}=\frac{2 k n_{D}}{60}, f_{D 4}=\frac{k n_{D}}{2 \cdot 60}$ & $\begin{array}{l}k=1,2-\text { harmonic number; } \\
n_{D}-\text { crankshaft speed } \min ^{-1}\end{array}$ \\
\hline $\begin{array}{l}\text { 4. Transfer of piston to cylinder- } \\
\text { piston group, } f_{D 5}\end{array}$ & $f_{D 5}=\frac{b z k n_{D}}{60}$ & $\begin{array}{l}\mathrm{b}-\text { number of transfers } \\
\text { according to the diagram of } \\
\text { normal forces; } \mathrm{z} \text { - the number of } \\
\text { engine cylinders }\end{array}$ \\
\hline 5. Friction in root bearings of shaft, $f_{D 6}$ & $f_{D 6}=\frac{z_{T} k n_{D}}{60}$ & $z_{T}-$ the number of friction pairs \\
\hline 6. Valve strikes, $f_{D 7}$ & $f_{D 7}=\frac{z \cdot z_{K} k n_{D}}{60 m}$ & $\begin{array}{l}z_{K}-\text { number of valves of one } \\
\text { cylinder; } m-\text { the tact. }\end{array}$ \\
\hline
\end{tabular}




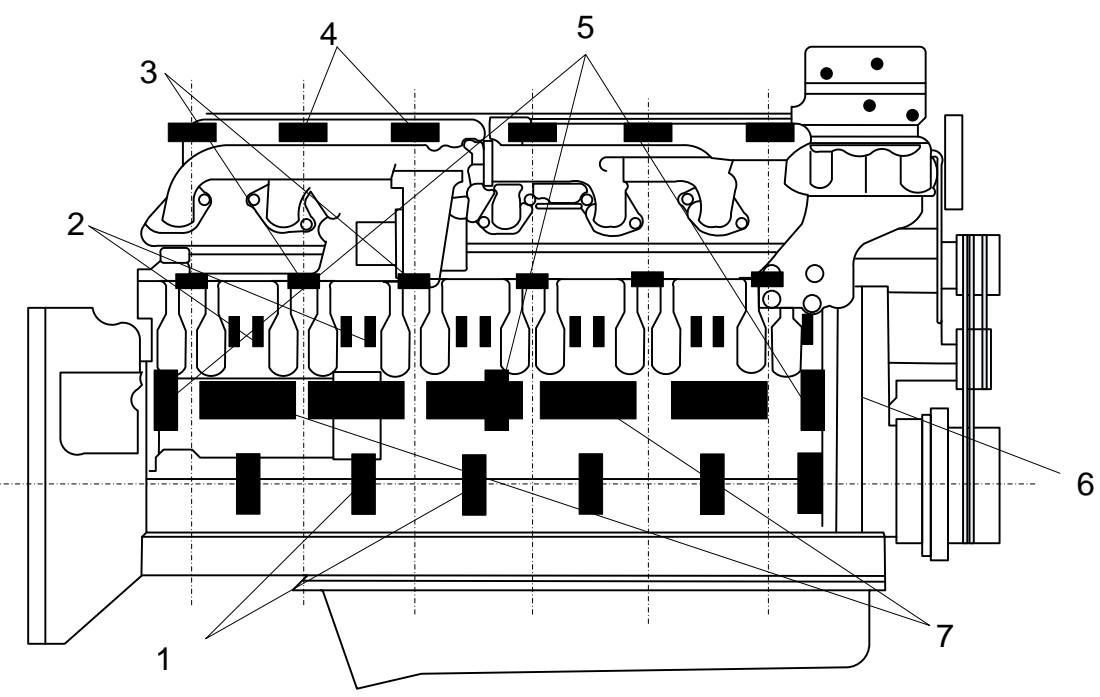

Fig. 3. Signal listening locations in engine connections: 1 - crankshaft - root bearing; 2 - connecting rod - bushing; 3 - valve - piston bottom; 4 - rocker arms - valve stem; 5 - camshaft - bearing; 6 - distribution gears; 7 - camshaft cam - pusher.

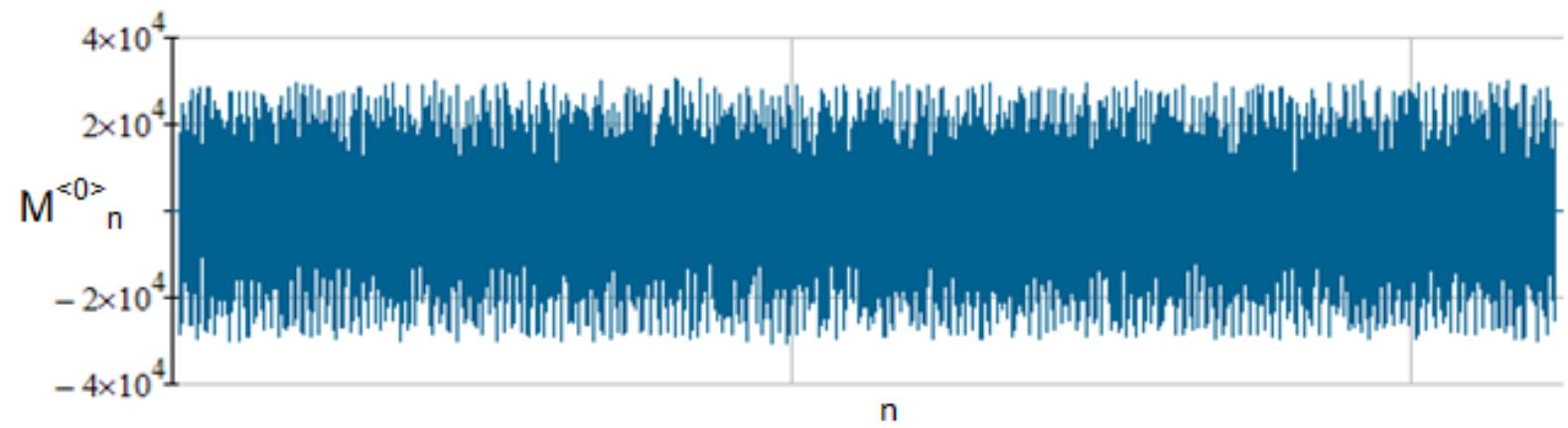

Fig. 4. Vibration signal of acceleration of the engine SMD-31A. (Sensor in zone 2 Fig. 3).

$$
\begin{aligned}
& \mathrm{F}:=\operatorname{cfft}\left(\mathrm{M}^{\langle 0\rangle}\right) \\
& \text { Minimumfrequency and step } \mathrm{d} ?:=\frac{1}{\mathrm{xmax}} \quad \mathrm{d} ?=6.104 \times 10^{-5} \\
& \text { Number of ordinates byfrequency } \quad \mathrm{m}:=1+2^{\mathrm{k}-1} \quad \mathrm{~m}=8.193 \times 10^{3}
\end{aligned}
$$$$
\text { Current frequency } \Omega_{\mathrm{j}}:=(\mathrm{j}+1) \cdot \frac{1}{\mathrm{xmax}} \quad \text { Maximumfrequency } \quad \Omega \max :=\mathrm{m} \cdot \mathrm{d} \Omega \quad \Omega \max =0.5
$$$$
\Omega_{0}=6.104 \times 10^{-5} \quad F_{0}=-1.015 \times 10^{4} \quad \Omega_{\mathrm{m}}=0.5 \quad F_{1024}=-5.363 \times 10^{3}+1.025 \mathrm{i} \times 10^{4}
$$

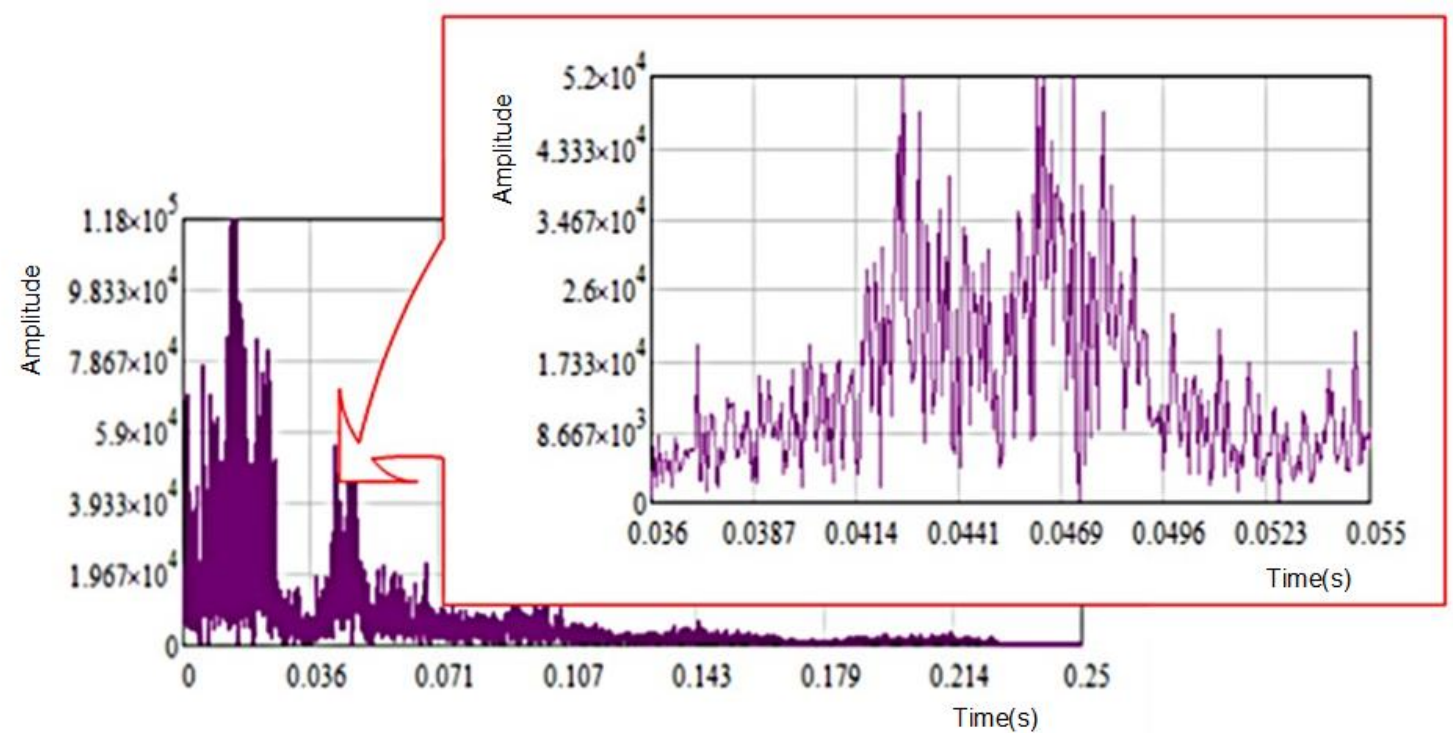

Fig. 5. Listing of receiving spectrum of vibroacoustic signal. 

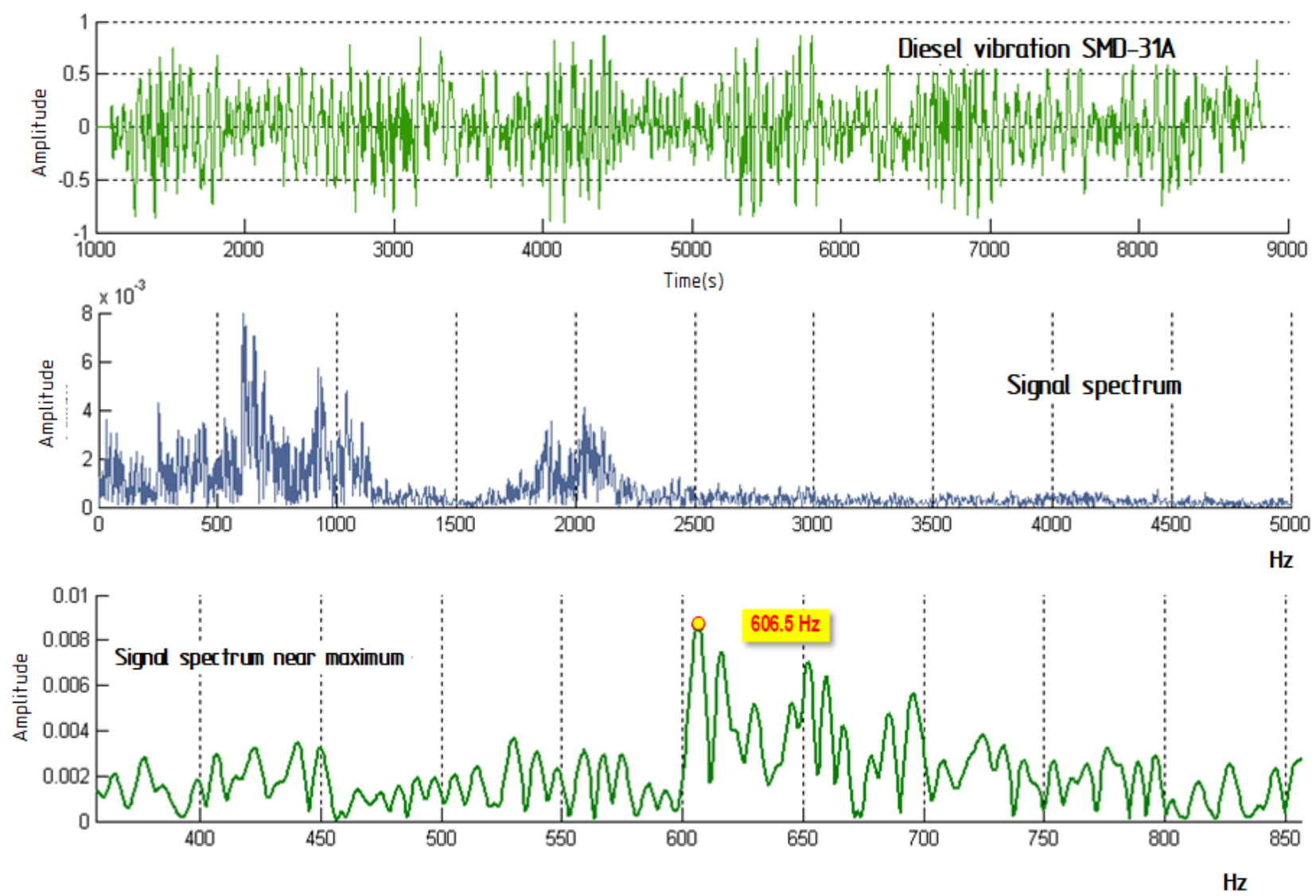

Fig. 6. Normalized vibration signal spectrum and its maximum are calculated.

Indeed, the signal spectrum obtained from any point of the engine contains information about all sources of vibration. However, the presence of previously considered characteristics of engine signals significantly complicates the analysis and interpretation of signals. Finding a solution in this direction is associated with improving the signal-to-noise ratio and improving the algorithm for interpreting the received signals based on their processing.

Usually, a fast Fourier transform is used to obtain the spectrum of the vibroacoustic signal. The Fourier transform is a change of function that converts it into a set of frequency components.

The Fourier transform is based on simple but extremely useful idea - almost any periodic function can be represented by the sum of individual harmonic components (sinusoids and cosines, with different amplitudes $A$, periods $T$ and frequencies $\omega$, respectively). The mathematical content of the Fourier transform is to represent the signal $y(x)$ as an infinite sum of sinusoids of form $F(\omega) \cdot \sin (\omega x)$. The function $F(\omega)$ is called a direct Fourier transform (integral). The inverse operation transforms the spectrum $F(\omega)$ into the output signal $y(x)$. The MathCad listing (Fig. 5) shows the obtaining the spectrum of the vibrating signal (Fig. 4) by the Fourier transform.

The main expressions for the Fourier transform of the input sequence $\left\{g_{n}\right\} n=0, \ldots, N-1$ are:

- direct

$G(k)=\frac{1}{N} \cdot \sum_{n=0}^{N-1} g(n) \cdot e^{-j \cdot \frac{2 \pi k n}{N}}$,

- inverted

$$
g(k)=\sum_{n=0}^{N-1} G(k) \cdot e^{-j \cdot \frac{2 \pi k n}{N}} .
$$

The calculation procedure for a discrete Fourier transform is a fast Fourier transform algorithm.

The spectral analysis frames are an estimate of the following characteristics:

- amplitude spectrum, power spectrum, power spectral density, complex spectrum;

- functions of coherence, coherent output power, "signal-interference" ratio.

Discrete Fourier Transform for process sampling $\left\{X_{k}\right.$, $k=0, \ldots, N-1\}$ is determined by the formula:

$$
F(n, N)=\frac{1}{N} \cdot \sum_{k=0}^{N-1} X_{k} \cdot e^{j \cdot \frac{2 \pi n k}{N}},
$$

The power density spectrum is defined as the average of $M$ realizations and has a dimension (unit/Hz).

$$
G_{c n u}(n, T)=\frac{1}{\Delta f} \cdot G_{c M},
$$

where: $\Delta f$ - poll frequency (sampling).

The amplitude spectrum is determined by the power spectrum and has the dimension (unit). This uses the dependency:

$$
G_{A}(n, T)=\sqrt{G_{c M}(n, T)} .
$$

The MathCad 15 and MathLab R2007b mathematical packages were used to develop a further adaptive model of vibration signal processing and analysis. This program contains a signal processing package. For fast Fourier transforms, MathCad has several standardized built-in functions, such as $f f t(y)$ and $F F T(y)$. 
The calculation results are reflected in the Fourier spectrum module because the spectrum itself is complex. An important parameter is the cut off frequency $\Omega_{0}=\frac{1}{x M A X}$ (defines the lower bound of the spectrum) and the Nyquist frequency $\Omega_{N}=\frac{N}{2 \cdot x M A X}$ (defines the upper bound of the spectrum).

The sampling interval of the Fourier spectrum is also equal $\Omega_{0}$, and the total number of calculation points is $\mathrm{N} / 2$. We use the functions ifft(y) and $\operatorname{IFFT}(y)$ to calculate the inverse Fourier transform (signal recovery over the true spectrum).

In the listing (Fig. 6), the normalized vibration spectrum was calculated using the MathLab package and the frequency of the maximum signal was found.

From the point of view of the analysis of vibroacoustic signals in the frequency domain and subsequent accurate recovery after a certain transformation, we can note a number of disadvantages of the Fourier series, which in general led to the Short-time Fourier transform and stimulated the development of wavelet transformations, which are beyond the scope of this article and will be discussed in the future. The disadvantages are:

- Limited informative analysis of non-stationary signals and almost no possibility of analysing their features (singularities), since in the frequency domain there is a "smearing" of features of the signals over the entire frequency range.

- The harmonic basis functions cannot reflect the variations of signals with infinite steepness of rectangular pulses, because they require an infinitely large number of members of a series.

The Fourier transform reflects global information on the frequency of the vibration signal and does not give a complete idea of the local properties of the signal in the conditions of rapid change of their spectral composition. The Fourier transform does not have the ability to analyse the frequency characteristics of the signal at any given time.

\section{Conclusions}

1. The simulation of the processing of the vibration signals of a diesel engine by means of spectral analysis showed that the use of fast Fourier transform and obtaining the spectrum of the entire signal is possible to use with the maximum approximation of the sensor to the oscillation source.

2. The use of the direct and inverse Fourier transform method should be used to increase the signal-to-noise ratio for the development of a further adaptive vibration signal processing model for the purpose of a clear diagnosis.

\section{Acknowledgements}

This work was supported by a grant of the Ministry of Science and Education of Ukraine, contract
110/495/01.01.2016, Project code: UA 164950101 , NULES Project title - "Experimental researches of parameters and modes of functioning of system of maintenance of agricultural machinery", phase 2: Experimental researches of parameters and modes of functioning of system of maintenance of harvesting combine.

\section{References}

1. Sergejeva N., Aboltins A., Strupule L., Aboltina B. (2018). Mathematical knowledge in elementary school and for future engineers. Proceedings of $17 \mathrm{th}$ International Scientific Conference "Engineering for rural development". Jelgava, Latvia, May 23-25, 2018, Latvia University of Agriculture. Faculty of Engineering. Vol. 17, 1166-1172.

2. Dubbini M., Pezzuolo A., De Giglio M., Gattelli M., Curzio L., Covi D., Yezekyan T., Marinello F. (2017). Last generation instrument for agriculture multispectral data collection. CIGR Journal, vol. 19, 158163.

3. Yata V.K., Tiwari B.C., Ahmad, I. (2018). Nanoscience in food and agriculture: research, industries and patents. Environmental Chemistry Letters, vol. 16, 7984.

4. Masek J., Novak P., Jasinskas A. (2017). Evaluation of combine harvester operation costs in different working conditions. Proceedings of 16th International Scientific Conference "Engineering for rural development". Jelgava, Latvia, May 24-26, Latvia University of Agriculture. Faculty of Engineering. Vol. 16, 1180-1185.

5. Rogovskii I., Grubrin O. (2018). Accuracy of converting videoendoscopy combine harvester using generalized mathematical model. Scientific Herald of National University of Life and Environmental Science of Ukraine. Series: technique and energy of APK. Kyiv, Ukraine. $\quad$ vol. 298, 149-156. doi: 10.31548/me.2018.04.149-156.

6. Viba J., Lavendelis E. (2006). Algorithm of synthesis of strongly non-linear mechanical systems. In Industrial Engineering - Innovation as Competitive Edge for SME, 22 April 2006. Tallinn, Estonia, 95-98.

7. Lио A.C.J., Guо Y. (2013). Vibro-impact Dynamics. Berlin: Springer-Verlag. 213.

8. Astashev V., Krupenin V. (2017). Efficiency of vibration machines. Proceedings of 16th International Scientific Conference "Engineering for rural development". Jelgava, Latvia, May 24-26, Latvia University of Agriculture. Faculty of Engineering. Vol. 16, 108-113.

9. Zagurskiy O., Ohiienko M., Rogach S., Pokusa T., Titova L., Rogovskii I. (2018). Global supply chain in context of new model of economic growth. Conceptual bases and trends for development of social-economic processes. Monograph. Opole. Poland, 64-74.

10. Drga R., Janacova D., Charvatova H. (2016). Simulation of the PIR detector active function. Proceedings of 20th International conference on Circuits, Systems, Communications and Computers (CSCC 2016), July 14-17, 2016, E D P Sciences, 17 Ave Du Hoggar Parc 
D Activites Coutaboeuf Bp 112, F-91944 Cedex A, France, vol. 76, UNSP 04036.

11. Novotny J. (2016). Technical and natural sciences teaching at engineering faculty of FPTM UJEP. Proceedings of 15th International Scientific Conference "Engineering for rural development". Jelgava, Latvia, May 23-25, Latvia University of Agriculture. Faculty of Engineering. Vol. 15, 16-20.

12. Pinzi S., Cubero-Atienza A.J., Dorado M.P. (2016). Vibro-acoustic analysis procedures for the evaluation of the sound insulation characteristics of agricultural machinery. Journal of Sound and Vibration, vol. 266 (3), 407-441.

13. Rogovskii I. L. (2019). Systemic approach to justification of standards of restoration of agricultural machinery. Machinery \& Energetics. Journal of Rural Production Research. Kyiv. Ukraine. Vol. 10, No 3, 181187.

14. Rogovskii I. L. (2019). Consistency ensure the recovery of agricultural machinery according to degree of resource's costs. Machinery \& Energetics. Journal of Rural Production Research. Kyiv. Ukraine. Vol. 10, No 4, 145 150 .

15. Rogovskii I. L. (2020). Algorithmicly determine the frequency of recovery of agricultural machinery according to degree of resource's costs. Machinery \& Energetics. Journal of Rural Production Research. Kyiv. Ukraine. Vol. 11. No 1. 155-162. DOI: 10.31548/machenergy.2020.01.155-162.

16. Rogovskii Ivan, Titova Liudmyla, Novitskii Andriy, Rebenko Victor. (2019). Research of vibroacoustic diagnostics of fuel system of engines of combine harvesters. Proceedings of 18th International Scientific Conference "Engineering for rural development". Jelgava, Latvia, May 22-25, Latvia University of Agriculture. Faculty of Engineering. Vol. 18. 291-298. DOI: 10.22616/ERDev2019.18.N451. Scopus. WoS.

\section{Список літератури}

1. Sergejeva N., Aboltins A., Strupule L., Aboltina B. Mathematical knowledge in elementary school and for future engineers. Proceedings of 17 th International Scientific Conference "Engineering for rural development". Jelgava, Latvia, May 23-25, 2018, Latvia University of Agriculture. Faculty of Engineering. Vol. 17, pp. 1166-1172.

2. Dubbini M., Pezzuolo A., De Giglio M., Gattelli M., Curzio L., Covi D., Yezekyan T., Marinello F. Last generation instrument for agriculture multispectral data collection. CIGR Journal, vol. 19, 2017, pp. 158-163.

3. Yata V.K., Tiwari B.C., Ahmad, I. Nanoscience in food and agriculture: research, industries and patents. Environmental Chemistry Letters, vol. 16, 2018, pp. 79-84.

4. Masek J., Novak P., Jasinskas A. Evaluation of combine harvester operation costs in different working conditions. Proceedings of 16th International Scientific Conference "Engineering for rural development". Jelgava, Latvia, May 24-26, 2017, Latvia University of Agriculture. Faculty of Engineering. Vol. 16, pp. 1180-1185.

5. Rogovskii I., Grubrin O. Accuracy of converting videoendoscopy combine harvester using generalized mathematical model. Scientific Herald of National University of Life and Environmental Science of Ukraine. Series: technique and energy of APK. Kyiv, Ukraine. vol. 298, 2018, pp. 149-156. doi: 10.31548/me.2018.04.149-156.

6. Viba J., Lavendelis E. Algorithm of synthesis of strongly non-linear mechanical systems. In Industrial Engineering - Innovation as Competitive Edge for SME, 22 April 2006. Tallinn, Estonia, pp. 95-98.

7. Luо A.C.J., Gио Y. Vibro-impact Dynamics. Berlin: Springer-Verlag, 2013. 213 p.

8. Astashev V., Krupenin $V$. Efficiency of vibration machines. Proceedings of 16th International Scientific Conference "Engineering for rural development". Jelgava, Latvia, May 24-26, 2017, Latvia University of Agriculture. Faculty of Engineering. Vol. 16, pp. 108-113.

9. Zagurskiy O., Ohiienko M., Rogach S., Pokusa T., Titova L., Rogovskii I. Global supply chain in context of new model of economic growth. Conceptual bases and trends for development of social-economic processes. Monograph. Opole. Poland, 2018, pp. 64-74.

10. Drga R., Janacova D., Charvatova H. Simulation of the PIR detector active function. Proceedings of 20th International conference on Circuits, Systems, Communications and Computers (CSCC 2016), July 1417, 2016, E D P Sciences, 17 Ave Du Hoggar Parc D Activites Coutaboeuf Bp 112, F-91944 Cedex A, France, vol. 76, UNSP 04036.

11. Novotny J. Technical and natural sciences teaching at engineering faculty of FPTM UJEP. Proceedings of 15th International Scientific Conference "Engineering for rural development". Jelgava, Latvia, May 23-25, 2016, Latvia University of Agriculture. Faculty of Engineering. Vol. 15, pp. 16-20.

12. Pinzi S., Cubero-Atienza A.J., Dorado M.P. Vibro-acoustic analysis procedures for the evaluation of the sound insulation characteristics of agricultural machinery. Journal of Sound and Vibration, vol. 266 (3), 2016, pp. 407-441.

13. Rogovskii I. L. Systemic approach to justification of standards of restoration of agricultural machinery. Machinery \& Energetics. Journal of Rural Production Research. Kyiv. Ukraine. 2019, Vol. 10, No 3, P. 181-187.

14. Rogovskii I. L. Consistency ensure the recovery of agricultural machinery according to degree of resource's costs. Machinery \& Energetics. Journal of Rural Production Research. Kyiv. Ukraine. 2019, Vol. 10, No 4, P. 145-150.

15. Роговський I. Л. Алгоритмічність визначення періодичності відновлення працездатності сільськогосподарських машин за ступенем витрат їх pecypcy. Machinery \& Energetics. Journal of Rural Production Research. Kyiv. Ukraine. 2020. Vol. 11. No 1. P. 155-162. DOI: 10.31548/machenergy.2020.01.155-162.

16. Rogovskii Ivan, Titova Liudmyla, Novitskii Andriy, Rebenko Victor. Research of vibroacoustic diagnostics of fuel system of engines of combine harvesters. Proceedings of 18th International Scientific Conference "Engineering for rural development". Jelgava, Latvia, May 22-25, 2019, Latvia University of Agriculture. Faculty of Engineering. Vol. 18. P. 291-298. DOI: 10.22616/ERDev2019.18.N451. Scopus. WoS. 
ДОСЛІДЖЕННЯ ВІБРОАКУСТИЧНОГО МЕТОДУ

КОНТРОЛЮ ТЕХНІЧНОГО СТАНУ ДИЗЕЛЬНОГО ДВИГУНА ЗЕРНОЗБИРАЛЬНИХ КОМБАЙНІВ ДЛЯ ВИЯВЛЕННЯ ПОЯВИ ДЕФЕКТІВ

\section{Д. І. Мартинюк}

Анотація. Автор дослідив віброакустичний метод контролю технічного стану дизельного двигуна зернозбиральних комбайнів за результатами аналізу пружних коливань, що розповсюджуються по корпусу і деталях, в результаті взаємодії останніх. У зв'язку з цим автори вирішували задачу цього методу, а саме виявлення віброакустичного сигналу, який викликаний співударами деталей досліджуваної кінематичної пари. При рішенні було враховано, що збільшення числа циліндрів двигуна веде до підвищення густоти віброімпульсів на одиницю фазового простору, тому цикл роботи дизельного двигуна зернозбиральних комбайнів було оцінено по куту повороту колінчастого валу. Так, встановлено, що фазовий простір тільки від газорозподільчого механізму заповнений віброімпульсами, що однозначно визначити технічний стан і-го з'єднання цього механізму за одним параметром неможливо. Для підвищення достовірності діагностування автори розглянули природу виникнення коливань в двигуні зернозбиральних комбайнів. Робота двигуна характерна тим, що робочі процеси у різних секціях проходять в рідні моменти часу, тому для виділення коливального процесу, пов'язаного з роботою окремої секції, чи окремого елементу однієї секції, використовують часову селекцію. Характер збудження коливальних процесів двигуна $\epsilon$ імпульсним, викликаний великою швидкістю наростання тиску в камері згорання, перекладкою поршнів, процесами впорскування палива і випуску відпрацьованих газів. Так зміни моменту впорскування палива, порушення у роботі газорозподільчого механізму, зносу поршневих кілець, збільшення зазору між поршнем і гільзою пов'язані 3 роботою цих механізмів імпульси зміщуються по фазі, змінюється їх амплітуда i тривалість, з'являються нові імпульси. При цьому одночасно діє декілька факторів, що викликають ускладнення віброакустичного сигналу. Для двигунів із кількістю циліндрів більше 4 співпадання в часі (накладання) сигналів, та неврівноваженість деталей під час обертання призводить до появи в спектрі сигналу частот 606,5 Гц.

Ключові слова: вібросигнал, дефект, амплітуда, коливання, двигун.

\section{ИССЛЕДОВАНИЕ ВИБРОАКУСТИЧЕСКОГО МЕТОДА КОНТРОЛЯ ТЕХНИЧЕСКОГО СОСТОЯНИЯ ДИЗЕЛЬНОГО ДВИГАТЕЛЯ ЗЕРНОУБОРОЧНЫХ КОМБАЙНОВ ДЛЯ ОБНАРУЖЕНИЯ ПОЯВЛЕНИЯ ДЕФЕКТОВ Д. И. Мартынюк}

Аннотация. Автор исследовал виброакустический метод контроля технического состояния дизельного двигателя зерноуборочных комбайнов по результатам анализа упругих колебаний, распространяющихся по корпусу и деталях, в результате взаимодействия последних. В связи с этим авторы решали задачу этого метода, а именно обнаружения виброакустического сигнала, который вызван співударами деталей исследуемой кинематической пары. При решении было учтено, что увеличение числа цилиндров двигателя ведет к повышению густоты віброімпульсів на единицу фазового пространства, поэтому цикл работы дизельного двигателя зерноуборочных комбайнов было оценено по углу поворота коленчатого вала. Так, установлено, что фазовое пространство только от газораспределительного механизма заполнен віброімпульсами, что однозначно определить техническое состояние і-го соединения этого механизма по одному параметру невозможно. Для повышения достоверности диагностирования авторы рассмотрели природу возникновения колебаний в двигателе зерноуборочных комбайнов. Работа двигателя характерна тем, что рабочие процессы в различных секциях проходят в родные моменты времени, поэтому для выделения колебательного процесса, связанного с работой отдельной секции или отдельного элемента одной секции, используют временную селекцию. Характер возбуждения колебательных процессов двигателя является импульсным, вызванный большой скоростью нарастания давления в камере сгорания, перекладкой поршней, процессами впрыска топлива и выпуска отработанных газов. Так изменения момента впрыска топлива, нарушения в работе газораспределительного механизма, износа поршневых колец, увеличение зазора между поршнем и гильзой связанные с работой этих механизмов импульсы смещаются по фазе, изменяется их амплитуда и длительность, появляются новые импульсы. При этом одновременно действует несколько факторов, вызывающих осложнения виброакустического сигнала. Для двигателей с количеством цилиндров больше 4 совпадения во времени (наложение) сигналов, и неуравновешенность деталей во время вращения приводит к появлению в спектре сигнала частот 606,5 Гц.

Ключевые слова: вибросигнал, дефект, амплитуда, колебания, двигатель.

\section{Д. I. Мартинюк ORCID 0000-0003-2681-0645.}

